This article was downloaded by: [University of Western Ontario]

On: 07 October 2014, At: 11:57

Publisher: Routledge

Informa Ltd Registered in England and Wales Registered Number: 1072954

Registered office: Mortimer House, 37-41 Mortimer Street, London W1T

3J H, UK

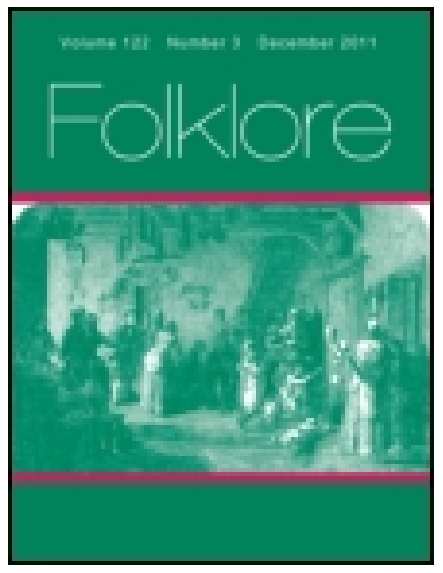

\title{
Folklore
}

Publication details, including instructions for authors and subscription information:

http:// www. tandfonline.com/loi/ rfol20

\section{Arthur and Gorlagon.}

Frank A. Milne \& Alfred Nutt

Published online: 06 Feb 2012.

To cite this article: Frank A. Milne \& Alfred Nutt (1904) Arthur and Gorlagon., Folklore, 15:1, 40-67, DOI: 10.1080/ 0015587X.1904.9719384

To link to this article: http:// dx. doi. org/ 10.1080/0015587X.1904.9719384

\section{PLEASE SCROLL DOWN FOR ARTICLE}

Taylor \& Francis makes every effort to ensure the accuracy of all the information (the "Content") contained in the publications on our platform. However, Taylor \& Francis, our agents, and our licensors make no representations or warranties whatsoever as to the accuracy, completeness, or suitability for any purpose of the Content. Any opinions and views expressed in this publication are the opinions and views of the authors, and are not the views of or endorsed by Taylor \& Francis. The accuracy of the Content should not be relied upon and should be independently verified with primary sources of information. Taylor and Francis shall not be liable for any losses, actions, claims, proceedings, demands, costs, expenses, damages, and other liabilities whatsoever or howsoever caused arising directly or indirectly in connection with, in relation to or arising out of the use of the Content.

This article may be used for research, teaching, and private study purposes. Any substantial or systematic reproduction, redistribution, reselling, loan, sub-licensing, systematic supply, or distribution in any form to anyone is 
expressly forbidden. Terms $\&$ Conditions of access and use can be found at http://www.tandfonline.com/page/terms-and-conditions 


\section{ARTHUR AND GORLAGON. ${ }^{1}$}

TRANSLATRD BY F. A. MILNE, WITH NOTHS BY A. NUT',

\section{(Read at Meeting, 17th December, 1903.)}

(1) Ar the City of the Legions King Arthur was keeping the renowned festival of Pentecost, to which he invited the great men and nobles of the whole of his kingdom, and when the solemn rites had been duly performed he bade them to a banquet, furnished with everything thereto pertaining. And as they were joyfully partaking of the feast of rich abundance, Arthur, in his excessive joy, threw his arms around the Queen, who was sitting beside him, and embracing her, kissed her very affectionately in the sight of all. But she was dumbfounded at his conduct, and, blushing deeply, looked up at him and asked why he had kissed her thus at such an unusual place and hour.

Arthur. Because amidst all my riches I have nothing so pleasing and amidst all my delights nothing so sweet, as thou art.

The Queen. Well, if, as you say, you love me so much, you evidently think that you know my heart and my affection.

Arthur. I doubt not that your heart is well disposed towards me, and I certainly think that your affection is absolutely known to me.

The Latin original has been edited for the first tlme by Professor G. L. Kittredge, of Marvard, from the late ith century Bodleian parchment MS. Rawlinson, $B$ 49, in Situdies and Notes in Philolosy and Literature, vol. viii., published by Ginn and Co. of Boston. The MS. contains another Latin Arthurian romance, Ilistoria Meriadoci regis Cambriae; Ilistoria trium Magorum ; Narratio de Tirio Appolonio ; Liber Alexandri . . de prelils ; Aristoteles de regimine sanitatis. Merindocus is also found in the B.M. MS. Cott. Faust, B. VI., whence it has been edited by another American Scholar, Professor J. Duuglas Bruce, in Publ. of the Mfod. Lang. Ass. of America, vol. xv. 
The Queen. You are undoubtedly mistaken, Arthur, for you acknowledge that you have never yet fathomed either the nature or the heart of a woman. Arthur. I call heaven to witness that if up to now they
have lain hid from me, I will exert myself, and sparing no pains, I will never taste food until by good hap I fathom
them.

(2) So when the banquet was ended Arthur called to him Caius, his sewer, and said, "Caius, do you and Walwain my nephew mount your horses and accompany me on the business to which I am hastening. But let the rest remain and entertain my guests in my stead until I return." Caius and Walwain at once mounted their horses as they were bidden, and hastened with Arthur to a certain king famed for his wisdom, named Gargol, who reigned over the neighbouring country; and on the third day they reached a certain valley, quite worn out, for since leaving home they had not tasted food nor slept, but had ever ridden on uninterruptedly night and day. Now immediately on the further side of that valley there was a lofty mountain, surrounded by a pleasant wood, in whose recesses was visible a very strong fortress built of polished stone. And Arthur, when he saw it at a distance, commanded Caius to hasten on before him with all speed, and bring back word to him to whom the town belonged. So Caius, urging on his steed, hastened forward and entered the fortress, and on his return met Arthur just as he was entering the outer trench, and told him that the town belonged to King Gargol, to whom they wero making their way. (3) Now it so happened that King Gargol had just sat down at table to dine; and Arthur, entering his presence on horseback, courteously saluted him and those who were feasting with him. And King Gargol said to him, "Who art thou $?$ and from whence? And wherefore hast thou entered into our presence with such haste?"

Arthur. "I am Arthur," he replied, "the King of 
Britain: and I wish to learn from you what are the heart, the nature, and the ways 's women, for 1 have very often heard that you are well skilled in matters of this kind."

Gargol. Yours is a weighty question, Arthur, and there are very few who know how to answer it. But take my advice now, dismount and eat with me, and rest to-day, for I see that you are overwrought with your toilsome journey; and to-morrow I will tell you what I know of the matter.

Arthur denied that he was overwrought, pledging himself' withal that he would never eat until he had learnt what he was in search of. At last, however, pressed by the King and by the company who were feasting with him, he assented, and, having dismounted, he sat at table on the seat which had been placed for him opposite the King. But as soon as it was dawn, Arthur, remembering the promise which had been made to him, went to King Gargol and said, "O my dear King, make known to me, I beg, that which you promised yesterday you would tell me to-day."

Gargol. You are displaying your folly, Arthur. Until now I thought you were a wise man : as to the heart, the nature, and the ways of woman, no one ever had a conception of what they are, and I do not know that I can give you any information on the subject. But I have a brother, King Torleil by name, whose kingdom borders on my own. $\mathrm{He}$ is older and wiser than $\mathrm{I}$ am : and indeed, if there is any one skilled in this matter, about which you are so anxious to know, I do not think it has escaped him. Seek him out, and desire him on my account to tell you what he knows of it.

(4) So having bidden Gargol farewell, Arthur departed, and instantly continuing his journey arrived after a four days' march at King 'Torleil's, and as it chanced found the King at dinner. And when the King had exchanged greetings
' Mins.
"Ingrenianm.
- Ars. 
with him and asked him who he was, Arthur replied that he was King of Britain, and had been sent to the King by his brother King Gargol, in order that the King might explain to him a matter, his ignorance of which had obliged him to approach the royal presence.

Torleil. What is it?

Arthur. I have applied my mind to investigate the heart, the nature, and the ways of women, and have been unable to find anyone to tell me what they are. Do you therefore, to whom I have been sent, instruct me in these matters, and if they are known to you, do not keep them back from me.

Torleil. Yours is a weighty question, Arthur, and there are few who know how to answer it. Wherefore, as this is not the time to discuss such matters, dismount and eat, and rest to-day, and to-morrow I will tell you what I know about them.

Arthur replied, "I shall be able to eat enough by-and-by. By my faith, I will never eat until I have learned that which I am in search of." Pressed, however, by the King and by those who were sitting at table with him, he at length reluctantly consented to dismount, and sat down at the table opposite the King. But in the morning he came to King Torleil and bcgan to ask him to tell what he had promised. Torleil confessed that he knew absolutely nothing about the matter, and directed Arthur to his third brother, King Gorlagon, who was older than himself, telling him that he had no doubt that Gorlagon was mighty in the knowledge of the things he was inquiring into, if indeed it was certain that anyone had any knowledge of them. (5) So Arthur hastened without delay to his destined goal, and after two days reached the city where King Gorlagon dwelt, and, as it chanced, found him at dinner, as he had found the others.

After greetings had been exchanged Arthur made known who he was and why he had come, and as he kept on asking 
for information on the matters about which he had come, King Gorlagon answered, "Yours is a weighty question. Dismount and eat: and to-morrow I will tell you what you wish to know."

But Arthur said he would by no means do that, and when again requested to dismount, he swore by an oath that he would yield to no entreaties until he had learned what he was in search of. So when King Gorlagon saw that he could not by any means prevail upon him to dismount, he said, "Arthur, since you persist in your resolve to take no food until you know what you ask of me, although the labour of telling you the tale be great, and there is little use in telling it, yet I will relate to you what happened to a certain king, and thereby you will be able to test the heart, the nature, and the ways of women. Yet, Arthur, I beg you, dismount and eat, for yours is a weighty question and few there are who know how to answer it, and when I have told you my tale you will be but little the wiser.

Arthur. Tell on as you have proposed, and speak no more of my eating.

Gorlagon. Well, let your companions dismount and eat.

Arthur. Very well, let them do so.

So when they, had seated themselves at table, King Gorlagon said, \%/Arthur, since you are so eager to hear this business, give ear, and keep in mind what I am about to tell you."

(6) (Here begins about the wolf.)

There was a king well known to me, noble, accomplished, rich, and far-famed for justice and for truth. He had provided for himself a delightful garden which had no equal, and in it he had caused to be sown and planted all kinds of trees and fruits, and spices of different sorts : and among the other shrubs which grew in the garden there 
was a beautiful slender sapling of exactly the same height as the King himself, which broke forth from the ground and began to grow on the same night and at the same hour as the King was born. Now concerning this sapling, it had been decreed by fate that whoever should cut it down, and striking his head with the slenderer part of it, should say, "Be a wolf and have the understanding of a wolf," he would at once become a wolf, and have the understanding of a wolf. And for this reason the King watched the sapling with great care and with great diligence, for he had no doubt that his safety depended upon it. So he surrounded the garden with a strong and steep wall, and allowed no one but the guardian, who was a trusted friend of his own, to be admitted into it; and it was his custom to visit that sapling three or four times a day, and to partake of no food until he had visited it, even though he should fast until the evening. So it was that he alone understood this matter thoroughly.

(7) Now this king had a very beautiful wife, but though fairto look upon she did not prove chaste, and her beauty was the cause of her undoing. For she loved a youth, the son of a certain pagan king; and preferring his love to that of her lord, she had taken great pains to involve her husband in some danger so that the youth might be able lawfully to enjoy the embraces for which he longed. And observing that the King entered the garden so many times a day, and desiring to know the reason, she often purposed to question him on the subject, but never dared to do so. But at last one day, when the King had returned from hunting later than usual, and according to his wont had entered the plantation alone, the Queen, in her thirst for information, and unable to endure that the thing should be concealed from her any longer (as it is customary for a woman to wish to know everything), when her husband had returned and was seated at table, asked him with a treacherous smile why he went to the garden so many times a day, and had 
been there even then late in the evening before taking food. The King answered that that was a matter which did not concern her, and that he was under no obligation to divulge it to her; whereupon she became furious, and improperly suspecting that he was in the habit of consorting with an adulteress in the garden, cried out, "I call all the gods of heaven to witness that I will never eat with you henceforth until you tell me the reason." And rising suddenly from the table she went to her bedchamber, cunningly feigning sickness, and lay in bed for three days without taking any food.

(8) On the third day, the King, perceiving her obstinacy and fearing that her life might be endangered in consequence, began to beg and exhort her with gentle words to rise and eat, telling her that the thing she wished to know was a secret which he would never dare to tell anyone. To which she replied, "You ought to have no secrets from your wife, and you must know for certain that I would rather die than live, so long as I feel that I am so little loved by you," and he could not by any means persuade her to take refreshment. Then the King, in too changeable and irresolute a mood and too devoted in his affection for his wife, explained to her how the matter stood, having first exacted an oath from her that she would never betray the secret to anyone, and would keep the sapling as sacred as her own life.

The Queen, however, having got from him that which she had so dearly wished and prayed for, began to promise him greater devotion and love, although she had already conceived in her mind a device by which she might bring about the crime she had been so long deliberating. So on the following day, when the King had gone to the woods to hunt, she seized an axe, and secretly entering the garden, cut down the sapling to the ground, and carried it away with her. When, however, she found that the King was returning, she concealed the sapling under her slecve, which 
hung down long and loose, and went to the threshold of the door to meet him, and throwing her arms around him she embraced hith as though she would have kissed him, and then suddenly thrust the sapling out from her sleeve and struck him on the head with it once and again, crying, "Be a wolf, be a wolf," meaning to add "and have the understanding of a wolf," but she added instead the words "have the understanding of a man." Nor was there any delay, but it came about as she had said; and he fled quickly to the woods with the hounds she set on him in pursuit, but his human understanding remained unimpaired. (9) Arthur, see, you have now learned in part the heart, the nature, and the ways of woman. Dismount now and eat, and afterwards I will relate at greater length what remains. For yours is a weighty question, and there are few who know how to answer it, and when I have told you all you will be but little the wiser.

Arthur. The matter goes very well and pleases me much. Follow up, follow up what you have begun.

Gorlagon. You are pleased then to hear what follows. Be attentive and I will proceed. (ro) Then the Queen, having put to flight her lawful husband, at once summoned the young man of whom 1 have spoken, and having handed over to him the reins of government became his wife. But the wolf, after roaming for a space of two years in the recesses of the woods to which he had fled, allied himself with a wild she-wolf, and begot two cubs by her. And remembering the wrong done him by his wife (as he was still possessed of his human understanding), he anxiously considered if he could in any way take his revenge upon her. Now near that wood there was a fortress' at which the Queen was very often wont to sojourn with the King. And so this human woll, looking out for his opportunity, took his she. wolf with her cubs one evening, and rushed unexpectedly into the town', and finding the two little boys of whom the

' Castelium.

In ipsis valuis pirgls. 
aforesaid youth had become the father by his wife, playing by chance under the tower without anyone to guard them, he attacked and slew them, tearing them fruelly limb from limb. When the bystanders saw too late what had happened they pursued the wolves with shouts. The wolves, when what they had done was made known, fled swiftly away and escaped in safety. The Queen, however, overwhelmed with sorrow at the calamity, gave orders to her retainers to keep a careful watch for the return of the wolves. No long time had elapsed when the wolf, thinking that he was not yet satisfied, again visited the town with his companions, and meeting with two noble counts, brothers of the Qucen, playing at the very gates of the palace, he attacked them, and tearing out their bowels gave them over to a frightful death. Hearing the noise, the servants assembled, and shutting the doors caught the cubs and hanged them. But the wolf, more cunning than the rest, slipped out of the hands of those who were holding him and escaped unhurt.

Arthur, dismount and eat, for yours is a weighty question and there are few who know how to answer it. And when I have told you all, you will be but little the wiser. ${ }^{2}$

(I I) Gorlagon. The wolf, overwhelmed with very great grief for the loss of his cubs and maddened by the greatness of his sorrow, made nightly forays against the flocks and herds of that province, and attacked them with such great slaughter that all the inhabitants, placing in ambush a large pack of hounds, met together to hunt and catch him; and the wolf, unable to endure these daily vexations, made for a neighbouring country and there began to carry on his usual ravages. However, he was at once chased from thence by the inhabitants, and compelled to go to a third country : and now he began to vent his rage with implacable fury, not only against the beasts but also against

"Arthur's refusal should follow, but there is no blank in the MS."G. L. Kittradge. 
human beings. Now it chanced that a king was reigning over that country, young in years, of a mild disposition, and far-famed for his wisdom and industry: and when the countless destruction both of men and beasts wrought by the wolf was reported to him, he appointed a day on which he would set about to track and hunt the brute with a strong force of huntsmen and hounds. For so greatly was the wolf held in dread that no one dared to go to rest anywhere around, but everyone kept watch the whole night long against his inroads.

So one night when the wolf had gone to a neighbouring village, greedy for bloodshed, and was standing under the eaves of a certain house listening intently to a conversation that was going on withis, it happened that he heard the man nearest him tell how the King had proposed to seek and track him down on the following day, much being added as to the clemency and kindness of the King. When the wolf heard this he returned trembling to the recesses of the woods, deliberating what would be the best course for him to pursue. ( $x$ ) In the morning the huntsmen and the King's retinue with an immense pack of hounds entered the woods, making the welkin ring with the blast of horns and with shouting; and the King, accompanied by two of his intimate friends, followed at a more moderate pace. The wolf concealed himself near the road where the King was to pass, and when all had gone by and he saw the King approaching (for he judged from his countenance that it was the King) he dropped his head and ran close after him, and encircling the King's right foot with his paws he would have licked him affectionately like a suppliant asking for pardon, with such groanings as he was capable of. Then two noblemen who were guarding the King's person, seeing this enormous wolf (for they had hever seen any of so vast a size), cried out, "Master, see here is the wolf we seek! see, here is the woll we seek! strike him, slay him, do not let the hateful beast attack us!" VOL. $x v$. 
The wolf, utterly fearless of their cries, followed close after the King, and kept licking him gently. The King was wonderfully moved, and after looking at the wolf for some time and perceiving that there was no fierceness in him, but that he was rather like one who craved for pardon, was much astonished, and commanded that none of his men should dare to inflict any harm on him, declaring that he had detected some signs of human understanding in him; so putting down his right hand to caress the wolf he gently stroked his head and scratched his ears. Then the King seized the wolf and endeavoured to lift him up to him. But the wolf, perceiving that the King was desirous of lifting him up, leapt up, and joyfully sat upon the neck of the charger in front of the King.

The King recalled his followers, ${ }^{2}$ and returned home. (13) He had not gone far when lo! a stag of vast size met him in the forest pasture with antlers erect. Then the King said, "I will try if there is any worth or strength in my wolf, and whether he can accustom himself to obey my commands." And crying out he set the wolf upon the stag and thrust him from him with his hand. The wolf, well knowing how to capture this kind of prey, sprang up and pursued the stag, and getting in front of it attacked it, and catching it by the throat laid it dead in sight of the King. Then the King called him back and said, "Of a truth you must be kept alive and not killed, seeing that you know how to show such service to us." And taking the wolf with him he returned home.

Arthur, dismount and eat. For yours is a weighty question, and there are few who know how to answer it; and when I have told you all my tale you will be but little the wiser.

Arthur. If all the gods were to cry from heaven "Arthur, dismount and eat," I would neither dismount nor eat until I had learnt the rest.

(14) Gorlagon. So the woll remained with the King, and 
was held in very great affection by him. Whatever the King commanded him he performed, and he never showed any fierceness towards or inflicted any hurt upon any one. He daily stond at table before the King at dinner time with his forepaws erect, eating of his bread and drinking from the same cup. Wherever the King went he accompanied him, so that even at night he would not go to rest anywhere save beside his master's couch.

Now it happened that the King had to go on a long journey outside his kingdom to confer with another king, and to go at once, as it would be impossible for him to return in less than ten days. So he called his Queen, and said, "As I must go on this journey at once, I commend this wolf to your protection, and I command you to keep him in my stead, if he will stay, and to minister to his wants." But the Queen already hated the wolf because of the great sagacity which she had detected in him (and as it so often happens that the wife hates whom the husband loves), and she said, "My lord, I am afraid that when you are gone he will attack me in the night if he lies in his accustomed place and will leave me mangled." The King replied, "Have no fear of that, for I have detected no such symptom in him all the long time he has been with me. However, if you have any doubt of it, I will have a chain made and will have him fastened up to my bed-ladder." I So the King gave orders that a chain of gold should be made, and when the wolf had been fastened up by it to the steps, he hastened away to the business he had on hand.

Arthur, dismount and eat. For yours is a weighty question, there are few who know how to answer it; and when $I$ have told you all my tale you will be but little the wiser.

Arthur. I have no wish to eat; and I beg you not to invite me to eat any more.

\footnotetext{
"It cum ad snai suppedanium ligrari. . . qua lupo aá scansils tigato. Suppedanium, a ladder by which one can climb on to a high bed. Siansile, scandile, the steps by which one can mount a horse, a horse-block.
} 
(15) Gorlagon. So the King set out, and the wolf remained with the Queen. But she did not show the care for him which she ought to have done. For he always lay chained, up though the King had commanded that he should be chained up at night only. Now the Queen loved the King's sewer with an unlawful love, and went to visit him whenever the King was absent. So on the eighth day after the King had started, they met in the bedchamber at midday and mounted the bed together, little heeding the presence of the wolf. And when the wolf saw them rushing into each other's impious embraces he blazed forth with fury, his eyes reddening, and the hair on his neck standing up, and he began to make as though he would attack them, but was held back by the chain by which he was fastened. And when he saw they had no intention of desisting from the iniquity on which they had embarked, he gnashed his teeth, and dug up the ground with his paws, and venting his rage over all his body, with awful howls he stretched the chain with such violence that it snapped in two. When loose he rushed with fury upon the sewer and threw him from the bed, and tore him so savagely that he left him half-dead. But to the Queen he did no harm at all, but only gazed upon her with venom in his eye. Hearing the mournful groans of the sewer, the servants tore the door from its hinges and rushed in. When asked the cause of all the tumult, that cunning Queen concocted a lying story, and told the servants that the wolf had devoured her son, and had torn the sewer as they saw while he was attempting to rescue the little one from death, and that he would have treated her in the same way had they not arrived in time to succour her. So the sewer was brought half dead to the guest-chamber. But the Queen fearing that the King might somehow discover the truth of the matter, and considering how she might take her revenge on the wolf, shut up the child, whom she had represented as having been devoured by the wolf, along with his nurse in an under- 
ground room far removed from any access; every one being under the impression that he had in fact been devoured.

Arthur, dismount and eat. For yours is a weighty question, and few there are who know how to answer it: and when I have told my tale you will be but little the wiser.

Arthur. I pray you, order the table to be removed, as the service of so many dishes interrupts our conversation.

(r6) Gorlagon. After these events news was brought to the Queen that the King was returning sooner than had been expected. So the deceitful woman, full of cunning, went forth to meet him with her bair cut close, and cheeks torn, and garments splashed with blood, and when she met him cried, "Alas! Alas! Alas! my lord, wretched that I am, what a loss have I sustained during your absence!" At this the King was dumbfounded, and asked what was the matter, and she replied, "That wretched beast of yours, of yours I say, which I have but too truly suspected all this time, has devoured your son in my lap; and when your sewer was struggling to come to the rescue the beast mangled and almost killed him, and would have treated me in the same way had not the servants broken in; see here the blood of the little one splashed upon my garments is witness of the thing." Hardly had she finished speaking, when lo! the wolf hearing the King approach, sprang forth from the bedchamber, and rushed into the King's embraces as though he well deserved them, jumping about joyfully, and gambolling with greater delight than he had ever done before. At this the King, distracted by contending emotions, was in doubt what he should do, on the one hand reflecting that his wife would not tell him an untruth, on the other that if the wolf had been guilty of so great a crime against him he would undoubtedly not have dared to meet him with such joyful bounds.

So while his mind was driven hither and thither on these matters and he refused food, the wolf sitting close by him touched his foot gently with his paw, and took the border of 
his cloak into his mouth, and by a movement of the head invited him to follow him. The King, who understood the wolf's customary signals, got up and followed him through the different bedchambers to the underground room where the boy was hidden away. And finding the door bolted the wolf knocked three or four times with his paw, as much as to ask that it might be opened to him. But as there was some delay in searching for the key-for the Queen had hidden it away-the wolf, unable to endure the delay, drew back a little, and spreading out the claws of his four paws he rushed headlong at the door, and driving it in, threw it down upon the middle of the floor broken and shattered. Then running forward he took the infant from its cradle in his shaggy arms, and gently held it up to the King's face for a kiss. ( 17 ) The King marvelled and said, "There is something beyond this which is not clear to my comprehension." Then he went out after the wolf, who led the way, and was conducted by him to the dying sewer; and when the wolf saw the sewer, the King could scarcely restrain him from rushing upon him. Then the King sitting down in front of the sewer's couch, questioned him as to the cause of his sickness, and as to the accident which had occasioned his wounds. The only confession, however, he would make was that in rescuing the boy from the woll, the wolf had attacked him; and he called the Queen to witness to the truth of what he said. The King in answer said, "You are evidently lying : my son lives: he was not dead at all, and now that I have found him and have convicted both you and the Queen of treachery to me, and of forging lying tales, I am afraid that something else may be false also. I know the reason why the wolf, unable to bear his master's disgrace, attacked you so savagely, contrary to his wont. Therefore confess to me at once the truth of the matter, else I swear by the Majesty of highest Heaven that I will deliver thee to the flames to burn." Then the wolf making an attack upon him pressed him close, and would have 
mangled him again had he not been held back by the bystanders.

What need of many words? When the King insisted, sometimes with threats, sometimes with coaxing, the sewer confessed the crime of which he had been guilty, and humbly prayed to be forgiven. But the King, blazing out in an excess of fury, delivered the sewer up to be kept in prison, and immediately summoned the chief men from the whole of his kingdom to meet, and through them he held an investigation into the circumstances of this great crime, Sentence was given. The sewer was flayed alive and banged. The Queen was torn limb from limb by horses and thrown into balls of flame.

Arthur, dismount and eat. For yours is a mighty question, and there are few who know how to answer it: and when I have told my tale you will be but little the wiser.

Arthur. If you are not tired of eating, you need not mind my fasting a little longer.

(18) Gorlagon. After these events the King pondered over the extraordinary sagacity and industry of the wolf with close attention and great persistence, and afterwards discussed the subject more fully with his wise men, asserting that a being who was clearly endued with such great intelligence must have the understanding of a man, "for no beast," he argued, "was ever found ta possess such great wisdom, or to show such great devotion to any one as this wolf has shown to me. For he understands perfectly whatever We say to him: he does what he is ordered: he always stands by me, wherever I may be: he rejoices when I rejoice, and when I am in sorrow, he sorrows too. And you must know that one who has avenged with such severity the wrong which has been done me must undoubtedly have been a man of great sagacity and ability, and must have assumed the form of a wolf under some spell or incantation." At these words the wolf, who was standing by the King, showed great joy, and licking his hands and feet and 
pressing close to his knees, showed by the expression of his countenance and the gesture of his whole body that the King had spoken the truth.

(19) Then the King said, "See with what gladness he agrees with what I say, and shows by unmistakable signs that I have spoken the truth. There can now be no further doubt about the matter, and would that power might be granted me to discover whether by some act or device I might be able to restore him to his former state, even at the cost of my worldly substance; nay, even at the risk of my life." So, after long deliberation, the King at length determined that the wolf should be sent off to go before him, and to take whatever direction he pleased whether by land or by sea. "For perhaps," said he, "if we could reach his country we might get to know what has happened and find some remedy for him."

So the wolf was allowed to go where he would, and they all followed after him. And he at once made for the sea, and impetuously dashed into the waves as though he wished to cross. Now his own country adjoined that region, being. however, separated from it on one side by the sea, though in another direction it was accessible by land, but by a longer route. The King, seeing that he wished to cross over, at once gave orders that the fleet should be launched and that the army should assemble.

Arthur, dismount and eat. For yours is a weighty question: and few there are who know how to answer it: and when I have told my tale you will be but little the wiser.

Arthur. The wolf being desirous of crossing the sea, is standing on the beach. I am afraid that if he is left alone he will be drowned in his anxiety to get over.

(2o) Gorlagon. So the King, having ordered his ship, and duly equipped his army, approached the sea with a great force of soldiers, and on the third day he landed safely at the wolf's country; and when they reached the shore the 
wolf was the first to leap from the ship, and clearly signified to them by his customary nod and gesture that this was his country. Then the King, taking some of his men with him, hastened secretly to a certain neighbouring city, commanding his army to remain on shipboard until he had looked into the affair and returned to them. However, he had scarcely entered the city when the whole course of events became clear to him. For all the men of that province, both of high and low degree, were groaning under the intolerable tyranny of the king who had succeeded to the wolf, and were with one voice lamenting their master, who by the craft and subtilty of his wife had been changed into a wolf, remembering what a kind and gentle master he was.

So having discovered what he wanted to know, and having ascertained where the king of that province was then living, the King returned with all speed to his ships, marched out his troops, and attacking his adversary suddenly and unexpectedly, slew or put to flight all his defenders, and captured both him and his Queen and made them subject to his dominion.

Arthur, dismount and eat. For yours is a mighty ques. tion: and there are few who know how to answer it: and when I have finished my tale you will be but little the wiser for it.

Arthur. You are like a harper who almost before he has finished playing the music of a song, keeps on repeatedly interposing the concluding passages without anyone singing to his accompaniment.

(21) Gorlagon. So the King, relying on his victory, assembled a council of the chief men of the kingdom, and setting the Queen in the sight of them all, said, " $O$ most, perfidious and wicked of women, what madness induced you to plot such great treachery against your lord! But I will not any longer bandy words with one who has been judged unworthy of intercourse with anyone; so answer 
the question I put to you at once, for I will certainly cause you to die of hunger and thirst and exquisite tortures, unless you show me where the sapling lies hidden with which you transformed your husband into a wolf. Perhaps the human shape which he has lost may thereby be recovered." Whereupon she swore that she did not know where the sapling was, saying that it was well known that it had been broken up and burnt in the fire. However, as she would not confess, the King handed her over to the tormentors, to be daily tortured and daily exhausted with punishments, and allowed her neither food nor drink. So at last, compelled by the severity of her punishment, she produced the sapling and handed it to the King. (22) And the King took it from her, and with glad heart brought the wolf forward into the midst, and striking his head with the thicker part of the sapling, added these words, "Be a man and have the understanding of a man." And no sooner were the words spoken than the effect followed. The wolf became a man as he had been before, though far more beautiful and comely, being now possessed of such grace that one could at once detect that he was a man of great nobility. The King seeing a man of such great beauty metamorphosed from a wolf standing before him, and pitying the wrongs the man had suffered, ran forward with great joy and embraced him, kissing and lamenting him and shedding tears. And as they embraced each other they drew such long protracted sighs and shed so many tears that all the multitude standing around were constrained to weep. The one returned thanks for all the many kindnesses which had been shown him: the other lamented that he had behaved with less consideration than he ought. What more? Extraordinary joy is shown by all, and the King, having received the submission of the principal men, according to ancient custom, retook possession of his sovereignty. Then the adulterer and adulteress were brought into his presence, and he was consulted as to what he judged ought to be 
done with them. And he condemned the pagan king to death. The Queen he only divorced, but of his inborn clemency spared her life, though she well deserved to lose it. The other King, having been honoured and enriched with costly presents, as was befitting, returned to his own kingdom.

Now, Arthur, you have learned what the heart, the nature, and the ways of women are. Have a care for yourself and see if you are any the wiser for it. Dismount now and eat, for we have both well deserved our meal, I for the tale I have told, and you for listening to it.

(23) Arthur. I will by no means dismount until you have answered the question I am about to ask you.

Gorlagon. What is that?

Arthur. Who is that woman sitting opposite you of a sad countenance, and holding before her in a dish a human head bespattered with blood, who has wept whenever you have smiled, and who has kissed the bloodstained head whenever you have kissed your wife during the telling of your tale?

Gorlagon. If this thing were known to me alone, Arthur (he replied), I would by no" means tell it you; but as it is well known to all who are sitting at table with me, I am not ashamed that you also should be made acquainted with it. That woman who is sitting opposite me, she it was who, as I have just told you, wrought so great a crime against her lord, that is to say against myself. In me you may recognise that wolf who, as you have heard, was transformed first from a man into a wolf, and then from a wolf into a man again. When $I$ became a wolf it is evident that the kingdom to which I first went was that of my middle brother, King Gorleil. And the King who took such great pains to care for me you can have no doubt was my youngest brother, King Gargol, to whom you came in the first instance. And the bloodstained head which that woman sitting opposite me embraces in the dish 
she has in front of her is the head of that youth for love of whom she wrought so great a crime against me. For when I returned to my proper shape again, in sparing her life, I subjected her to this penalty only, namely, that she should always have the head of her paramour before her, and that when I kissed the wife I had married in her stead she should imprint kisses on him for whose sake she had committed that crime. And I had the head embalmed to keep it free from putrefaction. For I knew that no punishment could be more grievous to her than a perpetual exhibition of her great wickedness in the sight of all the world. (24) Arthur, dismount now, if you so desire, for now that I have invited you, you will, so far as I am concerned, from henceforth remain where you are.

So Arthur dismounted and ate, and on the following day returned home a nine days' journey, marvelling greatly at what he had heard.

Frank A. Milne.

\section{NOTES.}

The foregoing tale, apart from a possible reference by Madden (Sir Gawayne, p. x., note), seems to have escaped the notice of all Arthurian students until Professor G. L. Kittredge of Harvard edited it last year, and made it the subject of what I do not hesitate to pronounce one of the most remarkable and valuable examples of storyological research known to me. In what follows I do little more than summarise and paraphrase Professor Kittredge's investigation, with the addition of certain views of my own, and I would strongly urge all interested in mediæval romance and in folktale research not to content themselves with my summary but to refer to and master the original. Professor Kittredge should not be held responsible for any imperfections in my expo. sition of his masterly argument, the plan of which I have not thought it necessary to retain.

It will at once be apparent to a storyologist of any experience that the task which Arthur has to achieve is one in which success is only possible by the aid, unwillingly given, of a supernatural 
personage upon whom pressure has to be put, in this case, the refusal to partake of his hospitality; a pressure analogous to that legally recognised in the codes of Brahminic India and early Ireland for the purpose of exacting settlement of debt. As in most tales of this class, the supernatural helper at first succeeds in eluding the request of his mortal applicant. Twice Arthur yields to the invitation to dismount and eat, and it is only on his showing himself firm that, at the third attempt, he meets with success. Professor Kittredge's conjecture that the three kings are in reality one and the same personage must command universal assent. The three names (if we disregard Torleil as due to a scribal error) are variant Welsh terms signifying Werwolf, and in fact etymologically allied to the 'Teutonic term. ${ }^{1}$ The story thus follows the familiar conventions of fairydom-the supernatural helper is compelled to give the mortal three chances, and that mortal, stupid or incurious though he be, always pulls off the third one.

But if this is so, our version has obviously suffered modification. The second and third kings cannot be the werwolfs brothers, as is indeed evident from the conduct of the story. The werwolf knows nothing of the third king when he appeals to him for protection, which would be absurd if he were really his brother. The statement really testifies to a confused reminiscence of the essential identity of the three informants. Furthermore, traces of contamination are glaringly evident. There is "superfuity of naughtiness" in the duplication of the adultery theme; and the Gellert episode-the false accusation resting upon the wolf of having slain the child-is dragged in clumsily. On the other hand, the form and conduct of the story wear an archaic and genuine folk character; the triadic arrangement, the repeated attempts, couched in a set formula, to induce Arthur to desist, find their parallels in the phenomena of popular story-telling generally, but especially in those of Gaelic popular story-telling as it still flourishes, and as it can be proved to have flourished for the last eight hundred years at least. No one familiar with Gaelic story-telling (whether in its Irish or Scotch form) can fail to

\footnotetext{
'Corlagon is by metathesis for Gorgalon, an expanded form of Gorgol I Old Welsh Gurwol or Guorgwol, the first syllable of which is cognate to wilin vir, Anglo-Saxon wer, whilst the second was equated by Professor Rhys whit the Ciermanic wolf over twenty years ago.
} 
recognise in Arthur and Gorlagon an example of the genre. Thus by the end of the fourteenth century at the latest, a Celtic and characteristically Celtic folktale was put into Latin, probably suffering in this transition from a vernacular to a learned language those modifications which are immediately apparent, as also, possibly, others. The Latin narrator had a Welsh original, as is proved by the forms of the names : this original was almost cer tainly complete and homogeneous, as is evident from the "folk" character of the incidents and framework.

Let us now turn to the consideration of parallels. The closest is a folktale still widely current in Gaeldom (Professor Kittredge bases his analysis on some ten versions ranging over the entire Gaelic area from Kerry to the Hebrides), the type-example being Morraha (Larminie, West Irish Folk-Tale, reprinted in Jacobs, Mare Celtic Fairy Tales). Briefly, it runs thus:

The hero games with a supernatural being, wins twice, loses third time, has task laid upon him to obtain the sword of light and knowledge of the one story about woman. Acting on the advice of his (fairy) wife, hero rides to her father, is there furnished with another horse that brings him to owner of the sword of light, Niall. At a third attempt he secures the sword, and threatening the owner with it, learns, at the persuasion of latter's wife, the story. Niall knew language of animals, and casually learnt thereby the existence of the magic rod; he laughed, had, on his wife's insistence, to explain why, was by her changed first into a raven, then into a horse, fox, wolf. As wolf he is hunted by, but secures protection of, King, guards the latter's child against the attack of a monstrous hand, is accused, but, trusted by King, recovers the child, whose attend. ant he becomes, and whom he ultimately persuades to strike him with the magic rod and thereby effect his re-transformation to human shape. His wife offers to drown herself, but Niall says if she will keep the secret, he will. Niall afterwards tracks the monster of the hand, slays him, recovers the elder children of the King, and directs the hero how to deal with his supernatural adversary, who is the brother of the monster of the hand.?

' In this summary and in the references to Morraks in the following pages, use is made of the other variants; no one version preserves al lihe incidents and traits. 
The framework here, it will be seen, is more elaborate than in ARTHUR AND GORLAGON and is of a different nature. The mortal hero is set in motion by an inimical supernatural being, who wishes to be revenged upon his brother's slayer. He fails, in accordance with the convention of fairydom, as his success would be the hero's failure. The same contamination with the Gellert story appears as in ARTHUR AND Gorlagon; also with the theme of the Child-Stealing Monster. The triadic arrangement is not so rigidly kept. The werwolf's wife, instead of being an altogether repugnant personage for whom no punishment is too bad, is not borne upon hardly by the story-teller and comes off at the end quite easily. We may surmise from this that ARTHUR AND GoRLAGON in addition to modification by the Gellert story, has likewise been modified by one of the current medixval versions of the familiar Eastern stories of woman's faithlessness and punishment.

Turn we now to the Medixval parallels. Both style themselves "Breton lays"; one, the Lai de Melion, is certainly not later than 1250, and may be much earlier; the other, the Lai de Bisclaveret of Marie de France, is not later than 1180 .

In MrLION the hero, hunting in a wood, meets a beautiful woman who has come to him from Ireland, who loves but him alone and has never loved before; this falls in with a vow he had made to have no amie who had ever loved another. He marries her; she learns that he possesses a congenital talisman capable of transforming him into a wolf, lures from him the secret, makes use of it, and returns to her father, taking one of her husband's servants with her. The wolf, follows, becomes leader of a band, and ravages the country. The father-in-law organises a hunt, in which all the wolves are killed except the werwolf; the latter ingratiates himself with his wife's father, by whom he is protected against her. He then attaches himself to Arthur, who comes on a visit to Ireland. One day be sees the servant who had accompanied his wife, and attacks him. The bystanders would slay him, but $A$ rthur protects him, and divining a mystery, forces the servant to confess. Melion is re-transformed and comes to England with Arthur, leaving the guilty wife behind him.

This tale, as is evident, stands in close relation to both ARTHUR AND GORLAGon and to MORraha, and represents a simpler stage 
of development. The framework is lacking, as are also any signs of contamination from the Gellert and Attack on the Child themes. It has, however, obviously been modified to fit it into the Arthurian cycle, Arthur sharing with the werwolf's father-inlaw the rôle of the protector-king. The hero's relation to this personage explains how it is that he finds his wife at the Court, a point which Morraha has preserved, but for which it does not account. In the treatment of the wife MeLion is nearer to Morraha than to Arthur AND Gorlagon; although pronounced guilty, she is spared. The most notable feature is that preserved by the opening ; the hero is wooed by a maiden who comes from Ireland, and who returns to her own country when she has, as she thinks, got rid of him. The significance of this will be made plain presently.

In the Lai de Bisclaveret of Marie de France the story runs thus :

The hero is a born werwolf, compelled to pass three days of every week in his animal shape; the change is effected by putting off his clothes. The wife discovers this, hides the clothes, and marries a lover of hers. The hunt by the King takes place as in other versions; the werwolf wins the King's favour, resides at his court, and whilst there attacks his wife's second husband, and, later, his wife. The mystery is disclosed, the wife is compelled under torture to give up the clothes, the werwolf regains his human form, and the wife is banished with her second husband.

Here then is a simple and straightforward version of one of the themes, the main one, found in the allied stories. It cannot be derived either from MrLion or from the common original which may be assumed to lie at the back of ARTHUR AND GorLAGON and MORRaha. On the other hand it cannot be their sole source. It proves that what may be styled the IVerwolf's Tale proper once existed apart from the other elements found in Mrlion, Arthur and Gorlagon, and Morraila.

As regards the relationship of the other three versions, MELion cannot have come from the Welsh original of ARTuUR AND Gorlagon, as it lacks the framework, and as it has preserved an opening of which no traces are found in the Welsh tale. For the same reasons it cannot be the direct source of that tale; which again cannot have originated MORRAHA, as the latter has retained 
decided traces of that presentment of the wife found in MELION. We must thus assume that ARTHUR AND GORIJGON and MORRAHA go back to a common original, itself akin to MELIoN, but neither derived from, nor the source of, that version. This further source postulated for all three tales may be called $X$, and its first offshoot is Meloo, modified by insertion into the Arthur cycle. There was probably no framework-setting in $X$, as otherwise the absence of this feature in Mesion would be inexplicable. But at some date $X$ was set in a framework and in this stage gave rise to the Welsh original of Arthur and Gorlagon. It continued to live on in the Gaelicspeaking area subject to both elaboration and change, unitil it assumed that form in which it is still found among the peasantry of Ireland and Scotland. But $X$ itself, as we bave scen, cannot have come from Marie's lay; both must go back ultimately to a common source.

In endeavouring to reconstruct $X$, made up as we have seen of the IVerwolf's Tale (found separate in Bisclaverex) plus elements common to the other three versions, MELion is of most value, and after MELion the current folktales which, though recorded so much later than ArTHUR AND GORLAGON, may fairly be assumed to have retained archaic "folk" elements in a more perfect form. We saw above that both are distinguished from ARTHUR AND GORIAGON by the more lenient view taken of the wife's conduct and by the fact that the latter returns to her father's land whither she is followed by the transformed husband. Only Mrluon, however, has preserved the significant opening incident which, as Professor Kittredge conjectures, proves the wife to be of supernatural kin. He then reconstructs the basis of $X$ as follows : Allured, it may be, by the hero's prowess, the supernatural maiden comes to woo him, as is so frequently the case in Irish mythic romance. But she has left behind her a lover of her kin, who follows her, and after a while persuades her to return to their own land of Faery. Thither the mortal husband follows andshould recover her. Thus, indeed, the story runs in one of the most famous of old Irish mythic romances, the IVooing of Etain. Etain is an immortal, wife of Mider; reborn in mortal form she is met at a spring side by Eochaid, King of Ireland, who is seeking a wife, but will not be content save with one, "whom no man of the men of Erin had known before him." They wed; Mlider follows her to mortal land, wins her from Eochaid in a VOL, $\mathrm{XV}$, 
threefold gaming (an incident still found, though in different connection, in the current folktale), and carries her back to fairyland, whither Eochaid pursues them, ultimately recovering her.

A story, not necessarily the Wooing of Etain, but one constructed on similar lines, was, so Professor Kittredge assumes, amalgamated with the Wernolfs Tale in somewhat the same stage of development as we find the latter in Bisclaveret, and thus originated the postulated version $X$. The Werzolf's Tale itself must have passed through different stages of development corresponding to altered feelings respecting the subject matter. Originally we must assume that the werwolf was a sympathetic personage, firstly because in folk-story-telling the hero is sympathetic by definition, secondly, because in the culture stage to which we may fairly refer the first shaping of the story the halfanimal nature would not carry with it an idea of the repugnant or unhallowed. But such an idea undoubtedly did arise, and is reflected in the vast mass of werwolf stories and conceptions. $\Lambda$ stage may thus be postulated in which the wife (unsympathetic originally as being opposed to the hero, but not morally culpable), becomes the sympathetic personage. Still later, sympathy would be shifted back by exciting pity for the hero (originally an object of envy as possessor of a highly desirable power), as one subject to a degrading liability, and by attaching moral blame to the faithless wife. The oldest recorded version of Marie's Bisclaveret belongs to this stage of development.

The fusion of these two story-types, the one concerned with the love-affairs of a fairy damsel ultimately won and lost by mortal and immortal lover, the other, the Werwolfs Tale, dealing with the separation of husband and wife deliberately effected by the latter, offers, it will be seen, no theoretical difficulty. When it took place the Ktain type had already in all likelihood suffered considerable change. In the oldest stratum of Irish fairy mistress romances nothing is more notable than the position of the heroine. She woos; she bestows or withdraws her favours with absolute freedom; the mortal lover neither acquires nor claims any rights. But even within the range of Gaelic romance, closely though it clings to ancient convention, slightly as it is affected by nonGaelic culture, there can be traced a change from this superb, over-moral attitude on the part of the woman to one more consonant with ordinary buman conditions. The free self-centred goddess, regally prodigal of her love, jealously guarding her inde- 
pendence, becomes a capricious or faithless woman. Such a process would be facilitated and hastened by the fusion of the two story-types postulated above; what in either was equivocal in the character of the heroine would put on a darker aspect. The process affects the machinery of the tale as well as the attitude of the narrator; it facilitates the change by which, following the lines of another group of tales, the transformation of the werwolf is ascribed to inimically exercised magic instead of to a congenital attribute; its extreme development is reached in Arthur and Gormagon, partly remodelled as this is by the clerkly Latin translator upon the lines of the Eastern stories of woman's faithlessness so well represented in the Seven Sages cycle. It is noteworthy that the current folktale, whilst exhibiting the altered machinery, which indeed it still further alters and complicates, does not go to anything like the same length in the change of moral attitude. The popular tale retains a blurred but unmistakable kinship of sentiment with the old mythic romance.

I have only given the broad outlines of Professor Kittredge's admirable study; the reader must be referred to the original for the numerous detail pieces of investigation concerning special story-types and incidents, their action and interaction, the rationale of story-change, which make his work fascinating reading for the storyologist. Space fails me for further comment or criticism, but I may be allowed to emphasise two of his conclusions. He points out that ARTHur aND GorLacon has been preserved by a mere accident; were it unknown the use of MORRAHA "in elucidating the history of documents so venerable as the Breton lais" would certainly be criticised; "what, use a modern folktale?" it would be said, "how uncriticall" Yet the preservation of the Latin-Welsh tale does not make our use of the current folktale right, it only enables us to prove that it is right. The second conclusion I would state in Professor Kittredge's own words: "The specific results of our study are to emphasise the importance of Irish material, and even of 'modern Irish' folklore in settling these questions" (i.e., the influence of Celtic upon medixval romance).

Having steadfastly championed these views ever since my first work for the Folk-Lore Society, now near a quarter of a century Old, I may be permitted some satisfaction in finding them so ably urged by the distinguished scholar upon whom has fallen the mantle of Francis James Child. 